\title{
Sunflower meal in commercial layer diets formulated on total and digestible amino acids basis
}

- Author(s)
Casartelli EM 1
Filardi RS'
Junqueira OM ${ }^{1}$
Laurentiz $\mathrm{AC}^{2}$
Assuena $\mathrm{V}^{1}$
Duarte KF $\mathrm{F}^{1}$
Departamento de Zootecnia
Universidade Estadual Paulista
Faculdade de Ciências Agrárias e
Veterinárias - Campus de Jaboticabal
2 Departamento de Biologia e Zootecnia
Universidade Estadual Paulista
Faculdade de Engenharia de llha Solteira -
Campus de Ilha Solteira

Mail Address

EM Casartelli

Avenida Líbero Badaró, 810

14.870-540. Jaboticabal, SP, Brasil

E-mail: emcasartelli@yahoo.com.br

Keywords

Egg quality, nutrition, performance, poultry.

\section{ABSTRACT}

An experiment was conduced to evaluate the inclusion of sunflower meal (SBM) in commercial layer diets formulated on total or digestible amino acids basis. One hundred forty-four 41-week-old Lohmann LSL layers were distributed in a completely randomized experimental design in a $2 \times 4$ factorial arrangement with three replications of six birds each. Treatments consisted of a combination of four SBM inclusion levels $\operatorname{SBM}(0 \%, 4 \%, 8 \%$, and $12 \%)$ and feed formulation according two amino acid recommendations (total or digestible). The experimental period was divided into five periods of fourteen days. Performance parameters (egg production, feed intake, feed conversion, egg mass) were evaluated for each period. In the last two days of each period, three eggs per replication were collected to evaluate egg quality (Haugh units, specific gravity, egg weight, eggshell thickness, and eggshell percentage). Hens fed on total amino acid recommendation presented the highest values for egg weight. Diets formulated on digestible amino acids basis showed an improvement in eggshell percentage and egg specific gravity. SBM addition in commercial layer diets did not influence performance; however, increasing SBM dietary levels SBM improved eggshell quality.

\section{INTRODUCTION}

Feed is the main cost of poultry production, and often accounts for $60-65 \%$ of total costs of commercial egg production. Soybean meal is the conventional protein source in layer diets, and it is influenced by external fluctuations. Increasing ingredient prices remain the greatest single item that determines profit margins in poultry production. The best strategy to reduce costs is the development of diet formulation using alternative, locally available, ingredients, thereby decreasing feed costs. SBM is a well-established and relatively inexpensive protein source for poultry diets. In addition, it can be harvested two or three times a year in tropical areas, being a good alternative for oil producers and for the feed mill sector (Vieira et al., 1992). However, the use of SBM in poultry diets is limited by variations in its chemical composition, and the two main components apparently restricting its use are high fiber/low energy and low lysine contents (Senkoylu and Dale, 1999).

Variations in the chemical composition of SBM are a consequence of the different processing methods, which determine the composition of this ingredient use as feedstuff. The extent of dehulling is an important determinant of the protein and fiber content of the resulting meal, whereas the processing method influences fat content. High temperatures associated with processing can damage proteins and reduce the availability of several amino acids, particularly lysine. (Ravindran and Blair, 1992; Dale, 1996)

According to Cuca et al. (1973) and Michael \& Sunde (1985), SBM is 
relatively rich in sulfur amino acids, but if not used together with other proteins sources or synthetic amino acids, two amino acid deficiencies should be expected: lysine, as first limiting amino acid, and threonine. Some studies indicate that lysine is the first limiting amino acid in broiler diets containing SBM (McGinnis et al., 1948, Thomas et al., 1965, Rad \& Keshavarz, 1976); however, lysine supplementation to SBM-based layer diets does not appear to be as critical as in broiler diets because their lysine requirement is much lower (Senkoylu and Dale, 1999).

Unlike most other oilseed meals, SBM does not contain high concentrations of anti-nutritive factors. Milic et al. (1968) detected $1.56 \%$ of a tannin-like chlorogenic acid compound, which inhibits the activity of digestive enzymes, including trypsin, chymotrypsin, amylase, and lipase in sunflower seeds. Heating the seeds at $100^{\circ} \mathrm{C}$, or at $135^{\circ} \mathrm{C}$ for 5 hours, destroyed about $43 \%$ of this chlorogenic acid. On the other hand, there is no data on the effects of heat treatments on lysine availability (Senkoylu and Dale, 1999). The addition of methionine and choline are required to counteract the effect of chlorogenic acid when SBM is used in the diet (Swick, 1999).

Reports on the use of SBM in poultry diets are not always consistent, probably due to differences in plant variety, chemical composition, processing method, bird age, and food formulation techniques used in the various studies. Uwayjan et al. (1983) evaluated three levels of sunflower seeds $(10,20$, or $30 \%)$ in replacement of 15,30 , or $45 \%$ of soybean meal or $9.5,19$ or $28.6 \%$ of corn, respectively, in commercial layer diets during production phase aiming at establishing the best level of sunflower inclusion. Results indicated that all tested levels of sunflower seed inclusion promoted relative worse performance, and diet supplementation with lysine or methionine did not correct this negative result.

Michel \& Sunde (1985) verified standard performance in 12-20 week-old layers fed diets in which soybean meal was completely replaced by sunflower seed, with supplementation or not of lysine and/or methionine. Also working with 12-20 week-old layers, Pinheiro et al. (1999) observed that, up to the inclusion level of $21 \%$, SBM (with no lysine addition) did not impair bird performance.

On the other hand, Serman et al. (1997), evaluating the effect of decorticated SBM as protein source in commercial layer diets on production performance, concluded that diets formulated with this ingredient needed to be supplemented with lysine and also with an energy source. Karunajeewa et al. (1989) previously evaluated the inclusion of SBM, sunflower seed, and other byproducts of sunflower oil extraction in layer diets, and also concluded that this ingredient may replace up to $75 \%$ of the protein source when energy and essential amino acid are supplemented.

In a trial with broiler chickens, Furlan et al. (2001) evaluated the inclusion of increasing SBM levels, and found that soybean meal crude protein could be replaced by sunflower protein up to a level of $30 \%$ in diets with equal energy and amino acid (digestible methionine + cysteine and lysine) ratios, approximately corresponding to an inclusion of 15\%. Similar results were found by Pinheiro et al. (2002), who added 0\%, $4 \%, 8 \%$, or $12 \%$ of SBM in broiler chicken diets. No change in weight gain and feed intake from 3 to 42 days of age was observed.

The objective of the present study was to evaluate the performance and the egg quality of commercial layers fed diets with increasing SBM levels, and formulated on total or digestible amino acids basis.

\section{MATERIAL AND METHODS}

One hundred and forty-four commercial layers (Lohmann LSL) were housed in wire cages (25x40x40) in conventional layers houses at the Experimental Poultry Farm of Faculdade de Ciências Agrárias e Veterinárias (FCAV-Unesp). A completely randomized design was used, with three replications of six birds each, two hens per cage. The experiment started when the hens were 41 weeks of age, and consisted of five periods of fourteen days. Light was provided for 16 hours per day during the experimental period. Feed and water were offered ad libitum.

The treatments were distributed using a factorial arrangement $(2 \times 4)$, which consisted of the combination of two amino acid (AA) recommendations (TA or DA), and four SBM inclusion levels $(0 \%, 4 \%, 8 \%$, or $12 \%)$.

The experimental diets were formulated to supply the requirements of total or digestible amino acids, as recommended by Rostagno et al. (2000). The following treatments were defined:

- TA - 0\%, 4\%, 8\%, or $12 \% \rightarrow$ Total amino acid recommendations and $0 \%, 4 \%, 8 \%$, or $12 \%$ of SBM inclusion level, respectively;

- DA - 0\%, 4\%, $8 \%$, or $12 \% \rightarrow$ Digestible amino acid recommendations and $0 \%, 4 \%, 8 \%$, or $12 \%$ of SBM inclusion level, respectively.

The diets were formulated to provide the same levels 
of energy (2.85 Mcal ME/kg), calcium (3.70\%), and available phosphorus (0.34\%). Total amino acid based diets were formulated with $14.5 \%$ crude protein, and the digestible amino acid based diets with $12.8 \%$ crude protein. Analyzed SBM nutritional composition was $28 \%$ CP, $12.1 \%$ CF, 0.4\% Ca, $0.16 \%$ available phosphorus $\left(\mathrm{P}_{\mathrm{a}}\right)$, and $0.20 \% \mathrm{Na}$. The composition of the experimental diets, and calculated nutritional values are presented in Table 1.

Egg production (EP) was recorded daily, and the average of each replicate was expressed per period. All eggs produced during the last 2 days were used to evaluate specific gravity $\left(\mathrm{SG}-\mathrm{g} / \mathrm{cm}^{3}\right)$ by egg flotation method, and 3 eggs were randomly collected from each experimental unit in order to determine egg weight (EW - g), Haugh Units (HU), eggshell thickness (ST $-\mathrm{mm})$, and egg percentage (EP - \%). Feed intake ( $F I-g / b i r d / d a y)$, egg mass (EM - g), egg weight (EW $\mathrm{g}$ ), and feed conversion ratio (FCR - $\mathrm{kg}$ feed/ $\mathrm{kg}$ eggs) were measured at the end of each period.

The obtained data were submitted to analysis of variance, using the General Linear Mode/ procedure (GLM) of SAS ${ }^{\circledR}$ software (SAS Institute, 1996). Means were compared by the test of Tukey at 5\% probability. Regression analysis of SBM levels was performed using treatments based on total or digestible amino acid basis when the SBM level was significant, and the AAxSM interaction was not.

\section{RESULTS AND DISCUSSION}

Laying performance and egg quality parameters are present in Tables 2 and 3 . The results for performance parameters (Table 2), feed intake, egg production, egg mass, and feed conversion ratio, were not statistically different $(p>0.05)$ between amino acid feed formulation treatments. However, egg weight of birds fed the diet formulated on digestible amino acid basis was lower than egg weight of birds fed the total amino acid diet $(p<0.05)$. Interactions among SBM inclusion levels of and amino acid recommendations were not observed. There was no statistical difference ( $p>0.05$ ) among SBM inclusion levels of for performance parameters.

Egg quality results (Table 2) showed that SBM did not influence Haugh units. A linear response for SBM

\begin{tabular}{|c|c|c|c|c|c|c|c|c|}
\hline \multirow[t]{2}{*}{ Ingredients } & \multicolumn{4}{|c|}{ Total amino cid diets } & \multicolumn{4}{|c|}{ Digestible amino acid diets } \\
\hline & 0 & 4 & 8 & 12 & 0 & 4 & 8 & 12 \\
\hline Corn & 70.97 & 66.97 & 64.64 & 62.29 & 74.33 & 73.76 & 70.03 & 54.87 \\
\hline Soybean meal & 11.00 & 16.32 & 13.84 & 11.36 & 9.00 & 9.00 & 9.00 & 9.00 \\
\hline Sunflower meal & 0.00 & 4.00 & 8.00 & 12.00 & 0.00 & 4.00 & 8.00 & 12.00 \\
\hline Limestone & 6.34 & 8.41 & 8.39 & 8.37 & 8.48 & 8.45 & 8.41 & 8.36 \\
\hline Starch & 0.00 & 0.00 & 0.00 & 0.00 & 0.00 & 0.00 & 0.00 & 2.00 \\
\hline Corn gluten meal $60 \%$ CP & 5.53 & 0.00 & 0.00 & 0.00 & 3.73 & 1.59 & 0.00 & 0.00 \\
\hline Dicalcium phosphate & 1.35 & 1.35 & 1.35 & 1.35 & 1.40 & 1.38 & 1.38 & 1.41 \\
\hline Sand & 3.51 & 0.00 & 0.00 & 0.00 & 1.63 & 0.00 & 0.00 & 4.92 \\
\hline Vitam. Min. Suplement* & 0.50 & 0.50 & 0.50 & 0.50 & 0.50 & 0.50 & 0.50 & 0.50 \\
\hline Sodium chloride & 0.44 & 0.42 & 0.40 & 0.39 & 0.44 & 0.42 & 0.41 & 0.40 \\
\hline L-Lysine $\mathrm{HCl}(78 \%)$ & 0.23 & 0.07 & 0.10 & 0.14 & 0.29 & 0.27 & 0.24 & 0.23 \\
\hline DL-Methionine (98\%) & 0.08 & 0.11 & 0.09 & 0.08 & 0.13 & 0.14 & 0.14 & 0.14 \\
\hline Soybean oil & 0.00 & 1.83 & 2.67 & 3.50 & 0.00 & 0.43 & 1.84 & 6.13 \\
\hline Antioxidant & 0.02 & 0.02 & 0.02 & 0.02 & 0.02 & 0.02 & 0.02 & 0.02 \\
\hline L-Tryptophan (10\%) & 0.03 & 0.00 & 0.00 & 0.00 & 0.05 & 0.04 & 0.03 & 0.02 \\
\hline Total & 100.00 & 100.00 & 100.00 & 100.00 & 100.00 & 100.00 & 100.00 & 100.00 \\
\hline \multicolumn{9}{|l|}{ CALCULATED VALUE } \\
\hline Metab. energy (Mcal/Kg) & 2.85 & 2.85 & 2.85 & 2.85 & 2.85 & 2.85 & 2.85 & 2.85 \\
\hline Crude protein (\%) & 14.50 & 14.50 & 14.50 & 14.50 & 12.70 & 12.70 & 12.70 & 12.70 \\
\hline Crude Fibre (\%) & 1.88 & 2.53 & 2.84 & 3.14 & 1.81 & 2.26 & 2.67 & 2.89 \\
\hline Calcium (\%) & 3.70 & 3.70 & 3.70 & 3.70 & 3.70 & 3.70 & 3.70 & 3.70 \\
\hline Available phosphorus (\%) & 0.34 & 0.34 & 0.34 & 0.34 & 0.34 & 0.34 & 0.34 & 0.34 \\
\hline Sodium (\%) & 0.20 & 0.20 & 0.20 & 0.20 & 0.20 & 0.20 & 0.20 & 0.20 \\
\hline Aminoacids (\%) & \multicolumn{4}{|c|}{ Total amino acids } & \multicolumn{4}{|c|}{ Digestible amino acids } \\
\hline Lysine & 0.72 & 0.72 & 0.72 & 0.72 & 0.64 & 0.64 & 0.64 & 0.64 \\
\hline Met. + Cys & 0.62 & 0.62 & 0.62 & 0.62 & 0.56 & 0.56 & 0.56 & 0.56 \\
\hline Methionine & 0.35 & 0.36 & 0.35 & 0.35 & 0.35 & 0.35 & 0.35 & 0.36 \\
\hline Threonine & 0.55 & 0.56 & 0.56 & 0.56 & 0.42 & 0.42 & 0.42 & 0.42 \\
\hline Tryptophan & 0.16 & 0.16 & 0.16 & 0.16 & 0.15 & 0.15 & 0.15 & 0.14 \\
\hline
\end{tabular}

* Vitamin and mineral supplement added per kg of diet: Vit A - 8.000 Ul; Vit D3 - 2.000 Ul; Vit E - 50 mg; Vit K3 - 3 mg; Vit B1 - 1.5 mg; Vit B2

- 4 mg; Vit B6 - 0.12 mg. Vit B12 - 15 mcg; Folacin - 0.6 mg; Pantothenic Acid 10 mg; Niacine - 30 mg; Biotine - 0.1 mg; Choline - 300 mg; Iron

- 50 mg; Copper - 10 mg; Zinc - 70 mg; Manganese - 100 mg; lodine - 1 mg; Selenium - 0.3 mg; Antioxidant 50 mg. 


\begin{tabular}{|c|c|c|c|c|c|c|c|c|}
\hline Treatments & $\mathrm{FI}$ & EP & EW & EM & FCR & HU & SP & SG \\
\hline TA - 0 & 94.72 & 65.79 & 65.07 & 42.86 & 2.196 & 96.80 & 9.10 & 1.0825 \\
\hline TA - 4 & 91.84 & 71.32 & 64.00 & 45.71 & 2.013 & 95.77 & 9.43 & 1.0850 \\
\hline TA - 8 & 92.80 & 71.62 & 62.32 & 44.66 & 2.075 & 94.57 & 9.69 & 1.0863 \\
\hline TA - 12 & 93.56 & 76.12 & 63.30 & 48.12 & 1.919 & 95.11 & 9.49 & 1.0849 \\
\hline TA mean & 93.23 & 71.22 & $63.67^{A}$ & 45.34 & 2.051 & 95.56 & $9.43^{\mathrm{B}}$ & $1.0847^{\mathrm{B}}$ \\
\hline$D A-0$ & 94.45 & 68.20 & 62.80 & 42.78 & 2.150 & 96.16 & 9.62 & 1.0861 \\
\hline DA - 4 & 87.25 & 67.05 & 61.13 & 40.94 & 2.120 & 96.41 & 9.50 & 1.0849 \\
\hline$D A-8$ & 89.54 & 75.82 & 60.60 & 45.90 & 1.940 & 94.95 & 9.82 & 1.0874 \\
\hline DA - 12 & 88.98 & 67.12 & 64.26 & 43.17 & 2.055 & 96.94 & 9.70 & 1.0870 \\
\hline DA mean & 90.06 & 69.54 & $62.19^{\mathrm{B}}$ & 43.20 & 2.066 & 96.12 & $9.66^{A}$ & $1.0864^{\mathrm{A}}$ \\
\hline CV \% & 4.88 & 8.12 & 2.70 & 7.92 & 5.66 & 2.10 & 2.03 & 0.11 \\
\hline \multicolumn{9}{|c|}{ Factorial analysis } \\
\hline AA & Ns & NS & $<0.05$ & Ns & NS & NS & $<0.001$ & $<0.001$ \\
\hline SBM & Ns & NS & NS & NS & NS & NS & $<0.05^{1}$ & $<0.05^{2}$ \\
\hline AAxSBM & NS & NS & NS & N5 & NS & NS & NS & NS \\
\hline \multicolumn{9}{|c|}{ Regression analysis } \\
\hline Linear & NS & NS & NS & NS & NS & NS & $<0.05$ & $<0.01$ \\
\hline Quadratic & Ns & NS & NS & NS & NS & NS & NS & NS \\
\hline Cubic & Ns & NS & NS & NS & NS & NS & Ns & NS \\
\hline$R^{2}$ & - & - & - & - & - & - & 0.54 & 0.64 \\
\hline
\end{tabular}

$A, B$ - Means in the same column followed by the same letter are not significantly different $(P>0.05) .(1)-S P=9.3942+0.025 S B M\left(R^{2}=0.54\right)$.

$(2)-S G=1.0845+0.0002$ SBM $\left(R^{2}=0.64\right)$.

inclusion levels was observed for eggshell percentage and egg specific gravity $(p<0.05)$ : eggshell quality values improved as SMB inclusion levels increased $(P<0.05)$. Eggshell percentage and egg specific gravity values of hens fed digestible amino acid diets were higher $(p<0.05)$ as compared to hens fed total amino acid diets.

In terms of eggshell thickness, the results of AA and SBM treatments were not independent (Table 3). Eggshell was thicker with $8 \%$ SBM inclusion level in the total amino acid based diet. The diet with no SBM based on total amino acids presented the thinnest eggshell $(p<0.05)$. Significant results were not observed ( $p>0.05)$ among SMB inclusion levels in digestible amino acids based diets.

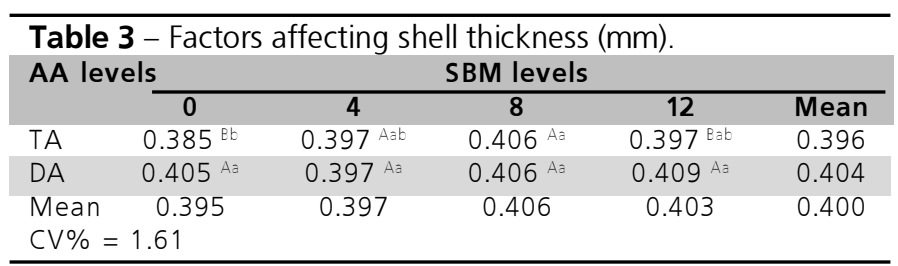

A, B - Means in the same column followed by the same letter are not significantly different $(P>0.05)$. $a, b$ - Means in the same row followed by the same letter are not significantly different $(P>0.05)$.

The results from the present study are consistent with findings from other authors. When evaluating decorticated SBM levels for layers $(0,5.79,12.19$, or $18.97 \%)$, Karunajeewa et al. (1989) did not find significant effects of these inclusion levels on egg production, egg mass, or feed conversion ratio; however, the authors observed that, as SMB inclusion levels increased, there was a trend of reduction in Haugh units. Similar results were found by Vieira et al. (1992). Egg weight, eggshell quality, and egg production were not affected by graded levels of SBM inclusion in layer diets $(13.5,27$, or $40.5 \%)$. On the other hand, positive linear effects were observed for feed intake and feed conversion ratio with SBM inclusions. Serman et al. (1997) used 24\% decorticated SBM in layer diets, and observed that, when lysine and energy were supplemented, bird performances were similar or higher as compared to birds fed diets with no SBM. Evaluating the same SBM inclusion levels as those used in the present study $(0,4,8$, and $12 \%)$ in broiler chicken diets, Pinheiro et al. (2002) did not observe any effect on feed intake or weight gain, but birds fed diets with no SBM $(0 \%)$ had a better feed conversion ratio from 3 to 35 days.

Consistent with the observations of the present study, Silva et al. (2000) did not find significant improvement in performance or egg quality in layers fed diets formulated on digestible amino acid requirements. According to these authors, the factor responsible for the negative results of digestible amino acid diets could be due to the different amino acid digestibilities, as the values presented in the chemical composition tables were calculated in trials using cecectomized roosters, and therefore cannot be directly applied to commercial layer diets. Similar results were found by Casartelli (2005) and Filardi et al. (2005 
and 2006). Under the conditions of their studies, diet formulation based on digestible amino acids did not show, in general, any improvement in egg quality.

The results of the present study suggest that layers appear to tolerate the higher levels of SBM, despite its higher crude fiber content, with no decrease in performance or egg quality parameters, which can be explained by the fact that layers have a more developed digestive system in terms of gut capacity as compared to broilers.

\section{CONCLUSION}

SBM can be used at $12 \%$ in layer diets without impaired performance and egg quality parameters. Diets formulated on digestible amino acid basis improved eggshell percentage and egg specific gravity, but resulted in lower egg weight.

\section{REFERENCES}

Casartelli EM, Filardi RS, Junqueira OM, Laurentiz AC, Assuena V, Duarte KF. Commercial Laying hens diets formulated according to different recommendations of total and digestible amino acids. Brazilian Journal of Poultry Science 2005; 7(3):177-180.

Cuca M, Avila E, Sosa E. Threonine supplementation to sunflower diets for chicks. Poultry Science 1973; 52(5):2016-2017.

Dale N. Variation in feed ingredient quality: oilseed meals. Animal Feed Science and Technology 1996; 59:129-135.

Filardi RS, Junqueira OM, Casartelli EM, Laurentiz AC, Duarte KF, Assuena $V$. Pearl millet utilization in commercial laying hen diets formulated on total and digestible amino acid basis. Brazilian Journal of Poultry Science 2005; 7(2):99-105.

Filardi RS, Casartelli EM, Junqueira OM, Laurentiz AC, Assuena V, Rodrigues EA. Formulação de rações para poedeiras com base em aminoácidos totais e digestíveis utilizando diferentes estimativas da composição de aminoácidos em alimentos. Revista Brasileira de Zootecnia 2006; 35(3):768-774.

Furlan AC, Mantovani C, Murakami AE, Moreira I, Scapinello C, Martins EN. Utilização do farelo de girassol na alimentação de frangos de corte. Revista Brasileira de Zootecnia 2001; 30(1):158164.

Karunajeewa H, Tham SH, Abu-Serewa S. Sunflower seed meal, sunflower oil and full-fat sunflower seeds, hulls and kernels for laying hens. Animal Feed Science and Technology 1989; 26(1):4549.

Keshavarz K, Jackson ME. Performance of growing pullets and laying hens fed low-protein, amino acid supplemented diets. Poultry Science 1992; 71(5):905-918.
McGinnis J, Hsu PT, Carver JS. Nutritional deficiencies of sunflower seed oil meal for chicks. Poultry Science 1948; 27:389-393.

Michael JN, Sunde ML. Sunflower meals in pullet developer diets. Poultry Science 1985; 64(5):669-674.

Milic B, Stojanovic S, Vucurevic N, Turcic M. Chlorogenic and quinic acids in sunflower meal. Journal of the Food Science and Agriculture 1968; 19:108-113.

Pinheiro JW, Fonseca NAN, Cabrera L, Sugeta SM, Otutumi LK, Ueno PM. Uso de rações contendo diferentes níveis de farelo de girassol e lisina na alimentação de frangas de postura de 6 a 18 semanas de idade. In: 36ª Reunião Anual da SBZ; 1999; Porto Alegre, Rio Grande do Sul, Brasil. CD-ROM.

Pinheiro JW, Fonseca NAN, Silva CA, Cabrera L, Bruneli FAT, Takahashi SE. Farelo de girassol na alimentação de frangos de corte em diferentes fases de desenvolvimento. Revista Brasileira de Zootecnia 2002; 31(3):1418-1425

Rad FH, Keshavarz K. Evaluation of nutritional value of sunflower meal and the possibility of substitution of sunflower meal for soubean meal in poultry diets. Poultry Science 1976; 55:17571765 .

Ravindran V, Blair R. Feed resources for poultry production in Asia and the Pacific. II. Plant protein sources. World's Poultry Science Journal 1992; 48:205-231.

Rostagno HS, Albino LFT, Donzele JL, Gomes PC, Ferreira AS, Oliveira RF, Lopes DC. Composição de alimentos e exigências nutricionais de aves e suínos: tabelas brasileiras. Viçosa, MG: UFV; 2000.141 p.

SAS. SAS ${ }^{\circledR}$ User's guide: statistics. Cary, NC; 1996.

Senkoylu N, Dale N. Sunflower meal in poultry diets: a review. World's Poultry Science Journal 1999; 55(6):153-174.

Serman V, Mas N, Melenjuk V, Dumanovski F, Mikulec Z. Use of sunflower meal in feed mixtures for laying hens. Acta Veterinarian Brno 1997; 66(4):219-227.

Swick RA. Considerations in using protein meals for poultry and swine. St Louis: American Soybean Association; 1999. (Technical Bulletin, AN21).

Thomas OP, Martin RS, Wessels JPH, Human JBB. Sunflower mealas surce of protein for chicken rations. South African Journal of Agricultural Science 1965; 8:1061-1068.

Uwayjan MG, Azar EJ, Daghir NJ. Sunflower seed in laying hen rations. Poultry Science 1983; 62(7):1247-1253.

Vieira SL, Penz Jr AM, Leboute EM, Corteline J. A nutritional evaluation of a high fiber sunflower meal. Journal Applied of Poultry Research 1992; 1(4):382-388. 